DOSSIÊ TEMÁTICO: Perspectivas para pensar as cidades: infâncias, educação, democracia e justiça

d०1 https://doi.org/10.22481/praxisedu.v16i40.6896

\title{
SEDICIOSAS FORMAS DE VIVER: CRIANÇAS, ARTE E COZINHA NA LUTA PELO DIREITO À MORADIA
}

\author{
UNREST WAYS OF LIVING: CHILDREN, ART AND CUISINE IN THE FIGHT FOR THE \\ RIGHT TO HOUSING
}
FORMAS SEDICIOSAS DE VIVIR: NIÑOS, ARTE Y GASTRONOMÍA EN LA LUCHA POR EL DERECHO A LA VIVIENDA

\author{
Marcia Aparecida Gobbi \\ Universidade de São Paulo - Brasil \\ Cleriston Izidro dos Anjos \\ Universidade Federal de Alagoas - Brasil
}

\begin{abstract}
Juliana Diamente Pito
Núcleo de Educação Infantil Paulistinha da Universidade Federal de São Paulo - Brasil
\end{abstract}

Resumo: Este artigo, derivado da pesquisa "Imagens de São Paulo: moradia e luta em regiões centrais e periféricas da cidade a partir de representações imagéticas criadas por crianças" tem como objetivo refletir sobre os encontros vividos dentro da Ocupação 9 de julho, que ocorrem mensalmente aos domingos, bem como sobre um encontro para crianças realizado no Ocupação Mauá, localizados na região central da cidade de São Paulo, SP. Que tramas enlaçam a elaboração de cardápios para os almoços dominicais? O que está implicado no ato de servir e de ser servido em reuniões regadas por boa comida e muitas pessoas? E quando essas práticas acontecem numa Ocupação resultante de luta pelo direito à moradia num dos maiores centros urbanos do país, o que isso implica? O que significa o almoço seguido de outras ações acontecendo num mesmo espaço físico, tais como shows, palestras, exposições em que as crianças são contempladas como sujeitos fundamentais à estas ações? Inferimos que a presença das Ocupações e suas atividades artísticas e sociais contribuem com os processos de transformação do entorno, alterando os modos de lidar e de viver nos locais em que estão localizadas. $\mathrm{O}$ texto se divide em dois grandes momentos - arte e comida - em que mulheres e crianças se encontram, configuram e constroem formas de lutar pelo direito à moradia e à cidade, revelando aquelas e aqueles que sofrem pelas constantes tentativas de apagamento e de silenciamento de suas humanidades no contexto das cidades.

Palavras chave: Luta por moradia. Infância e cidade. Mulheres e Crianças.

Abstract: This article, derived from the research "Images of São Paulo: housing and struggle in central
and peripheral regions of the city from imagery representations created by children" aims to reflect on
the encounters lived within the July 9 Occupation, which occur monthly to Sundays, as well as a meeting
for children held at Ocupação Mauá, located in the central region of the city of São Paulo, SP. What
plots link the elaboration of menus for Sunday lunches? What is involved in the act of serving and being
served in meetings watered by good food and many people? And when these practices take place in an
Occupation resulting from the struggle for the right to housing in one of the largest urban centers in the 
country, what does this imply? What does lunch mean, followed by other actions taking place in the same physical space, such as shows, lectures, exhibitions in which children are considered as fundamental subjects to these actions? We infer that the presence of the Occupations and their artistic and social activities contribute to the processes of transformation of the environment, changing the ways of dealing and living in the places where they are located. The text is divided into two major moments art and food - in which women and children meet, configure and build ways to fight for the right to housing and the city, revealing those and those who suffer from constant attempts to erase and silence people. their humanities in the context of cities.

Keywords: Fight for housing. Childhood and city. Women and Children.

Resumen: Este artículo, derivado de la investigación "Imágenes de São Paulo: vivienda y lucha en las regiones centrales y periféricas de la ciudad a partir de representaciones de imágenes creadas por niños" tiene como objetivo reflexionar sobre los encuentros vividos dentro de la Ocupación del 9 de julio, que ocurren mensualmente para Los domingos, así como una reunión para niños celebrada en Ocupação Mauá, ubicada en la región central de la ciudad de São Paulo, SP. ¿Qué parcelas vinculan la elaboración de menús para almuerzos dominicales? ¿Qué implica el acto de servir y ser servido en reuniones regadas por buena comida y mucha gente? Y cuando estas prácticas tienen lugar en una Ocupación resultante de la lucha por el derecho a la vivienda en uno de los centros urbanos más grandes del país, ¿qué implica esto? ¿Qué significa el almuerzo, seguido de otras acciones que tienen lugar en el mismo espacio físico, como espectáculos, conferencias, exposiciones en las que los niños son considerados sujetos fundamentales de estas acciones? Inferimos que la presencia de las ocupaciones y sus actividades artísticas y sociales contribuyen a los procesos de transformación del entorno, cambiando las formas de tratar y vivir en los lugares donde se encuentran. El texto se divide en dos momentos principales, arte y comida, en los que las mujeres y los niños se encuentran, configuran y construyen formas de luchar por el derecho a la vivienda y la ciudad, revelando a aquellos y a quienes sufren de constantes intentos de borrar y silenciar a las personas. sus humanidades en el contexto de las ciudades.

Palabras clave: Lucha por la vivienda. Infancia y ciudad. Mujeres y niños.

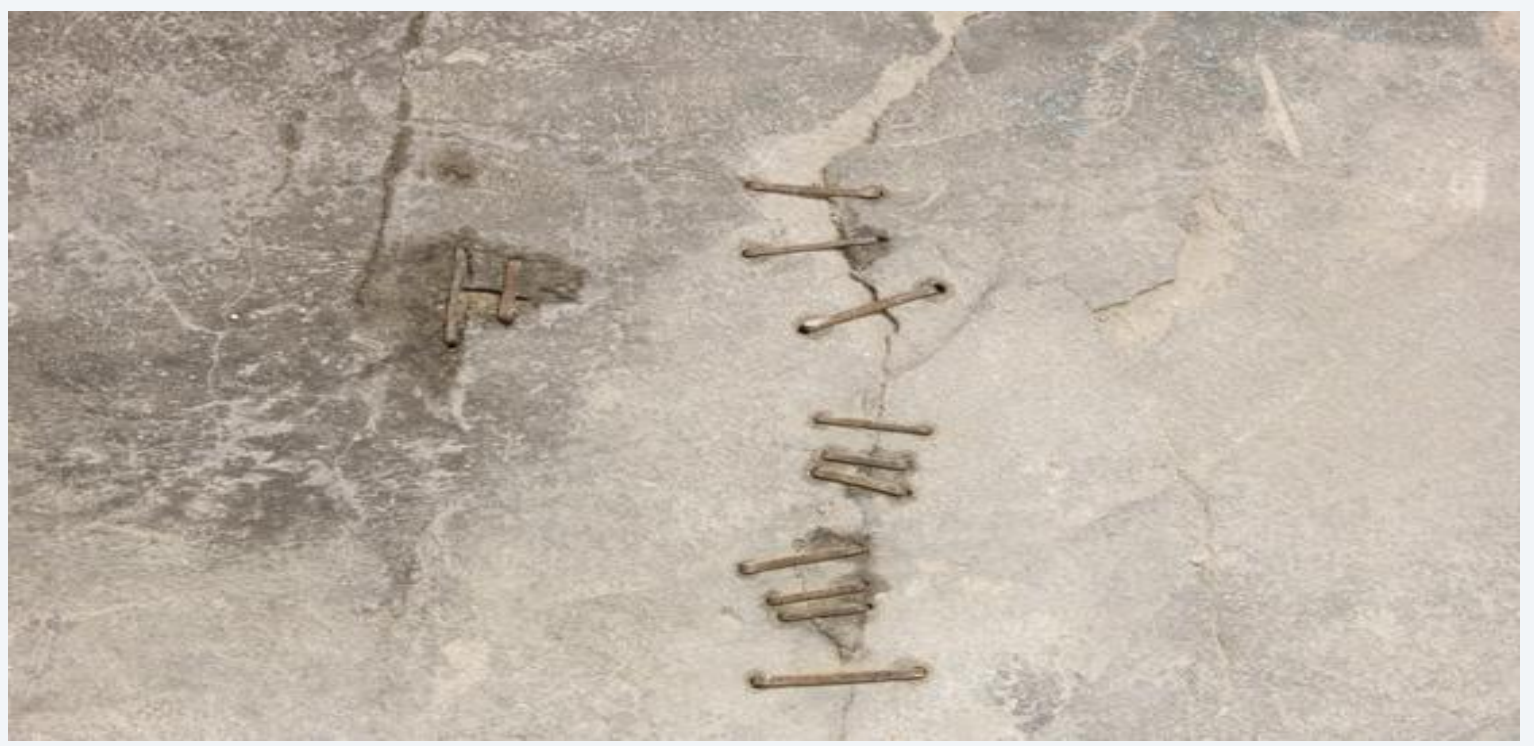

Kader Attia: Reparo tradicional, lesão imaterial' 2014-2016

Quem não luta tá morto. A pior luta é aquela que não fazemos. (Ivanete Araújo, tarde de algum sábado em 2019) 


\section{Ou, sobre encontros (im)possíveis antes e durante a pandemia}

Esse texto foi escrito em meio a uma pandemia. No exato momento em que escrevemos não há como afirmar o que o futuro nos reserva. Como sairemos desta situação é uma questão constante que se soma a outra, se sairemos. Falamos da Covid-19 que até o momento não tem cura, tem enorme letalidade e levou - e ainda leva - milhões de pessoas ao isolamento físico e deixa outras ao léu num agravamento da pobreza que sempre existiu. No caso brasileiro, vale ressaltar, não temos apenas a pandemia, mas um encavalamento de crises, merecendo destaque, a crise política, que adensa nossos problemas sociais, emocionais, culturais e provoca, ou intensifica, os efeitos devastadores de práticas políticas negacionistas e que descartam pessoas. Estamos durante, antes ou depois do nosso destino? Pergunta Nuno Ramos (2020) ao refletir sobre o fato de que temos uma pandemia particular na política brasileira, provocada especialmente pelo atual presidente da república. A sensação de descontinuidade do mundo nos acomete. Ele parece inverter seu curso na cessação de alguns dos modos como víamos e vínhamos até o momento, ao mesmo tempo, em que temos esgarçadas as desigualdades sociais sempre existentes em que o Estado se baseia na administração, não só da vida, mas da morte. Escrevemos mal ancoradas nessas condições que nos inspiraram a refletir sobre uma particularidade relacionada ao tema infância e cidade e seus desdobramentos. Em tom e pretensões ensaísticas pretendemos tratar do presente que ainda permite projetar o futuro, num momento em que nos sentimos no fundo de um poço que parece não ter fim.

Neste ensaio temos um objetivo e seu desdobre, são eles: Refletir sobre encontros dentro da Ocupação ${ }^{1} 9$ de Julho em almoços públicos dominicais que ocorrem mensalmente e sobre um encontro, entre vários, para crianças na Ocupação Mauá, frutos de observações ao longo do ano de 2019 derivadas da pesquisa Imagens de São Paulo: moradia e luta em regiões centrais e periféricas da cidade a partir de representações imagéticas criadas por crianças ${ }^{2}$. Mulheres e crianças destacam-se indissociáveis na cidade e nos lugares pesquisados como atores ${ }^{3}$ fundamentais num rico processo de construção de lutas cotidianas que ocorrem após a festa, ou melhor entendido, o momento em que os edifícios não cumpridores da função social da propriedade, são ocupados por aquelas e aqueles sem teto, que não têm onde morar. Ao tratar

\footnotetext{
1 Doravante, sempre que nos referirmos às ocupações 9 de Julho ou Ocupação Mauá, colocaremos a palavra Ocupação, com letra inicial maiúscula.

${ }^{2}$ Pesquisa com financiamento FAPESP (2017-11440/02).

${ }^{3}$ Considerar as crianças e mulheres como atores fundamentais de nossas pesquisas, implica em uma luta constante pela descolonização dos nossos modos de pensar e fazer pesquisa, enfrentando o adultocentrismo, as dicotomias diversas e considerando os marcadores da diferença, na busca constante por uma "reviravolta científica", conforme apontam Santos, Anjos e Faria (2017).
} 
disto nosso ensaio divide-se em dois grandes momentos em que mulheres e crianças se encontram presentes configurando formas sediciosas de lutar pelos direitos à moradia e à cidade mesclando-os à arte e a gastronomia e revelando o humano por trás da justa medida de lutas feitas ao longo de uma história de apagamentos na cidade.

Ambas as Ocupações estão localizadas numa área que abrange regiões comumente conhecidas como centro velho e centro novo da cidade de São Paulo. Optamos por este recorte por reconhecermos em ambas uma frutífera relação entre as propostas destes encontros e as crianças que os frequentam, moradoras ou não, a partir de atos políticos convergentes à arte. Destacamos a importância de apresentarmos recortes de suas propostas e práticas por tratarem de narrativas ainda hoje desqualificadas, vistas como menos relevantes, possivelmente por encontrarem-se entre mulheres moradoras de edifícios ocupados, tidos, por muitos, como invasão à propriedade privada, ainda que descumpridores de sua função social. Soma-se a isso o tratamento da cultura, tão desprezada ultimamente no país, que adquire o status de elevar e enlevar experiências citadinas, em destaque, o que é fundamental, com as crianças dentro de edifícios ocupados. Trazem compreensões importantes para pensarmos sobre crianças e mulheres no urbano em moradias ocupadas, objeto ainda pouco estudado academicamente, sobretudo quando gostaríamos de contar com elas como grupo com o qual podemos partir, não só para compreender a luta por moradia, mas a infância em diferentes contextos da vida urbana, configurando em sentido mais amplo, a luta pelo direito à cidade, que está conjugado aos direitos das crianças, desde bebês, e podem ser pensados a partir e com elas. Inferimos que a presença das Ocupações e suas atividades artísticas e sociais implica forte contribuição com processos de transformação do espaço circundante, alterando formas de lidar e construir o lugar nas regiões onde se encontram. A arte, em suas distintas manifestações, se faz presente de modo constante, como algo essencial à vida, expressando preocupação com a democratização de acesso aos bens culturais e sociabilidade. Ela está inserida entre os usos da cidade nestas Ocupações em projetos artísticos materializados em espaços não institucionais ${ }^{4}$. Esses encontros não têm o poder de promover a mudança das relações sociais, mas certamente não é possível passar incólume. Eles se constituem como rica oportunidade para aprender o convívio com o outro, além de mostrar a poiesis escondida por trás de um Brasil atualmente em ruínas e repercute, não uma arte estetizada e, por vezes, inalcançável, mas as agruras e conflitos numa saturada desigualdade social mostrando sutilmente outras possibilidades de relações entre

\footnotetext{
${ }^{4}$ Referimo-nos aqui à exposição O que não é Floresta é Prisão Política, inaugurada em setembro de 2019, na Ocupação 9 de Julho.
} 
pessoas. As práticas sociais por elas engendradas, que incluem crianças, desde bebês, promovem a circulação desta população infantil pela cidade, o que pode contribuir com seu processo de produção, ao modo das crianças. Vale ressaltar que práticas artísticas em Ocupações nas últimas décadas têm uma rica história na cidade de São Paulo, como revelam os estudos de Sebastião Oliveira Neto (2019) sobre as residências artísticas já existentes na Ocupação Prestes Maia, conferindo outras formas de pensar e ver arte pública ${ }^{5}$.

A metodologia da pesquisa compreendeu observações, conversas e uma entrevista com moradora implicada à organização dos almoços e atividades artísticas na Ocupação 9 de Julho, observações e conversas com adultas e crianças na Ocupação Mauá. Recorremos a fontes documentais como filmes e publicações em jornais e revistas online para aprofundar o entendimento dessas práticas que remetem a pensar sobre os papéis da cozinha e da festa como espaço de sociabilidades promotoras de práticas e atos políticos.

O espaço como produção social (LEFEBVRE, 2013) carrega e produz em seu interior possíveis fugas a um cotidiano programado. O que poderia ser pensado como produtor de desligamento e/ou alienação pode ser visto como criador de resistência e nisto reside o desdobre da primeira reflexão e objetivo propostos. As Ocupações, referentes empíricos para escrita deste artigo, são entendidas e problematizadas como obra dentro da obra/cidade, em seu cotidiano, e os dias destes encontros festivos como prática política e artística fundamental, que não apenas enlevam, mas apresentam aspectos da vida a partir de propostas de sociedade, com as crianças. Incrustadas na cidade visceralmente, apresentam-se como forças criadoras diante de um cenário de marginalização e criminalização de quem luta por seus direitos. É comum ouvirmos a emblemática expressão invasão e não ocupação estampada em jornais, proferida por algumas pessoas em diferentes condições, usada como xingamento em referência aos moradores e às moradoras de edifícios ocupados. Há, contudo, uma compreensão equivocada sobre os edifícios ocupados, sobre as ocupações e seus moradores. No equívoco construído propositadamente trata-se de fazer crer que são invasores da propriedade privada de terrenos ou prédios não habitados, por isso, ela não deriva da luta pelo direito à moradia, conforme Art $6^{\circ}$ da Constituição de 1988, em que está previsto: São direitos sociais a educação, a saúde, a alimentação, o trabalho, a moradia, o lazer, a segurança, a previdência social, a proteção à maternidade e à infância, a assistência aos desamparados, na forma desta Constituição.

\footnotetext{
5 Embora fuja do escopo deste ensaio, é importante conhecer outras ocupações que abrigam ou abrigaram exposições ou residências artísticas: Destaca-se a Ouvidor 63, na rua de mesmo nome, numa ocupação de artistas, em São Paulo. Em Pernambuco há o Movimento Ocupe Estelita, em Recife, no Cais de mesmo nome e outras tantas espalhadas pelo país e que, com seus movimentos, ocupam espaços e provocando a pensar sobre outros usos da cidade, bem como, a estetização da produção artística e seus mercados.
} 
Portanto, resultam de lutas pela vida e pelo direito à cidade que não podem deixar de ser compreendidas também do ponto de vista das crianças. Discussões sobre infância e cidade exigem que contemplemos vários segmentos da população excluídos de seus direitos, até mesmo de andar displicentemente pelas ruas, independente de raça, gênero, idade, ou de morar dignamente, entre tantos outros.

O primeiro referente que destacamos para a elaboração de nossas reflexões são os almoços onde reúnem-se pessoas de variadas origens, músicos, exposições artísticas, numa expressão da arte contra a banalização do cotidiano, e a gastronomia se faz em forma de "cozinha de ocupação". Eles ocorrem mensalmente na Ocupação 9 de Julho, com suas características particulares e que têm composto fissuras da luta pela moradia, transformando a Ocupação em lugar de experiência coletiva. Envolver-se nas festas e "cozinha" como campo de pesquisa nos permitiu apresentar elementos que vinculam essas manifestações ao desejo de compreender diferentes propostas e práticas que entendemos aqui como luta, ao mesmo tempo, que sua percepção faz exacerbar as noções de ocupar como algo vivido que se estende como direito e desejo, e invadir, como rotulação de caráter reducionista, moralizador e preconceituoso. Tais movimentações festivas, por discretas que pareçam entre um conjunto mais amplo de lutas a serem travadas e direitos a serem conquistados, apresentam-se como fios que levam ideias sobre organização de vida nos movimentos e nas ocupações, não como algo exótico a ser conhecido, mas como possível prenúncio de rupturas com modelos políticos e sociais carcomidos. Há uma responsabilidade social para com os envolvidos e envolvidas, sobretudo, pela dimensão política presente nos atos aqui apresentados.

Pareceu-nos relevante que algumas atividades sociais que se firmam nas dimensões política e artística em ocupações na cidade de São Paulo tivessem centralidade em nossas reflexões, sobretudo, aquelas que envolvem as crianças como coprodutoras e partícipes de processos de criação e de programações infantis, não somente dominicais. Ainda que de modo embrionário entende-se a existência de práticas que colocam em pautam outras gramáticas possíveis da vida urbana, em que a cidade estranha aos cidadãos que a habitam, indicando certo estado de alienação, torna-se cidade de aproximação ou apropriada por seus moradores e suas moradoras de todas as idades. Acreditamos que durante essa pandemia, no Brasil, acrescida de problema político de ampla gravidade, essa prática poderá servir como um ponto de partida para reflexões e constituição de um amanhã diferente e mais igualitário, ainda mais quando queremos pensar sobre infância e cidade. Escrevemos sobre e entre cicatrizes que se antecipam em estabelecer marcas resultantes de dor entre nós e na cidade, que mais esvaziada, nos mostra outras formas de vida no vazio esparramado por diferentes partes do mundo e de distintas 
maneiras. A partir de referências contidas no passado recente, nosso esforço é refletir num presente entre mundos e olhar para um futuro que nos tira o chão. Há um receio do que virá, mas certamente, partir deste tempo presente é condição imprescindível para se pensar sobre o futuro. Pensamos sobre propostas que principiam em movimentos de luta por moradia e incitam reflexões sobre outros modos de pensar a cidade e a luta por direitos. Acreditamos que retardar ou indicar caminhos, que nascem, dialeticamente da catástrofe, ora anunciada e agora vivida, é prática fundamental.

A pandemia inevitavelmente, nos aproximou de reflexões contidas no clássico "Sobre o conceito de História", em que Walter Benjamin, nos anos 1940, a partir de observações do quadro Angelus Novus, de Paul Klee, chama a atenção para o rosto que olha o passado e vê a catástrofe numa cadeia de acontecimentos cumulativa de ruínas. Ao debruçar-se sobre esse passado lança-se numa tentativa por reunir os vencidos e despertar os mortos, contudo, trata-se de ação inglória, já que os ventos o impelem ao futuro em que o suposto progresso se presentifica, impregnam suas asas atrás das quais as ruínas amontoam-se. Angústia. Contudo, o desalento ronda o anjo em agonia, mas também pode sinalizar para certo aprendizado, quiçá, para experiências satisfatórias, por aquilo que pode emergir de seu interior. Refletir sobre infância e cidade implica caminhar pelas ruas e encorajar-se a ver o que, encoberto há tempos, não víamos, ou passávamos absortos numa validada rotina de adultas e adultos cujos encontros furtivos com crianças ocorrem por acasos ou obrigações, mas poucas vezes resultam de seus direitos a usufruir coletivamente o urbano.

Como afirma Francesco Tonucci as crianças precisam ser consideradas como paradigmas para se pensar cidades para todas e todos, disto deriva mudanças profundas nas práticas sociais concernentes à orientação espacial e temporal das cidades. Tonucci materializa essas reflexões e delas fez e faz política pública conferindo centralidade às crianças. Ao criar o Laboratório das Crianças, na cidade de Fano, na Itália, e mantê-lo desde 1991 carrega e alimenta vivas as discussões sobre essas questões. Trata-se de afirmações, estudos e práticas fundamentais, diríamos revolucionárias. Tonucci apresenta inúmeras, importantes e contagiantes iniciativas para pensar numa "cidade das crianças", mas, quando tentamos aproximar suas proposituras das condições em que vivemos nas cidades brasileiras, delineamos uma pergunta: quais crianças? Há alguma segmentação que implicaria vozes mais audíveis e outras nem tanto? A resposta a esta questão exige amplas abordagens, afinal, de quais grupos sociais partiremos para compreender e mudar as cidades a partir das crianças? Nosso questionamento surge de observações sobre os usos da cidade por diferentes grupos infantis e o grande distanciamento existente entre eles originado pela classe social, gênero, raça, etnia. 
Há uma grotesca naturalização da desigualdade gerada por essa compleição social e que a mantém como se não fosse nada. Neste ensaio partimos destas preocupações. A precarização da vida tem sido vista a olhos nus esparramada entre pessoas que passam, outras que se alojam sob as pontes, transeuntes a procura de emprego e nos olhares dos passantes que buscam, apenas buscam. É neste contexto que resolvemos refletir sobre assuntos aparentemente banais: almoços e festas com crianças e para elas em Ocupações. Pretende-se tratar aqui das camadas que encobrem práticas sociais, onde, como diria De Certeau (1994) vivem os ordinários da cidade, entre eles mulheres e crianças cujas práticas tornadas invisíveis escrevem um texto urbano que, muitas vezes, não podem ler.

Não é a voz a que damos ouvidos um eco de outras já silenciadas? Benjamin, Teses sobre a história

\section{Arte e cozinha na ocupação: delicadeza e política, sem esquecer das crianças}
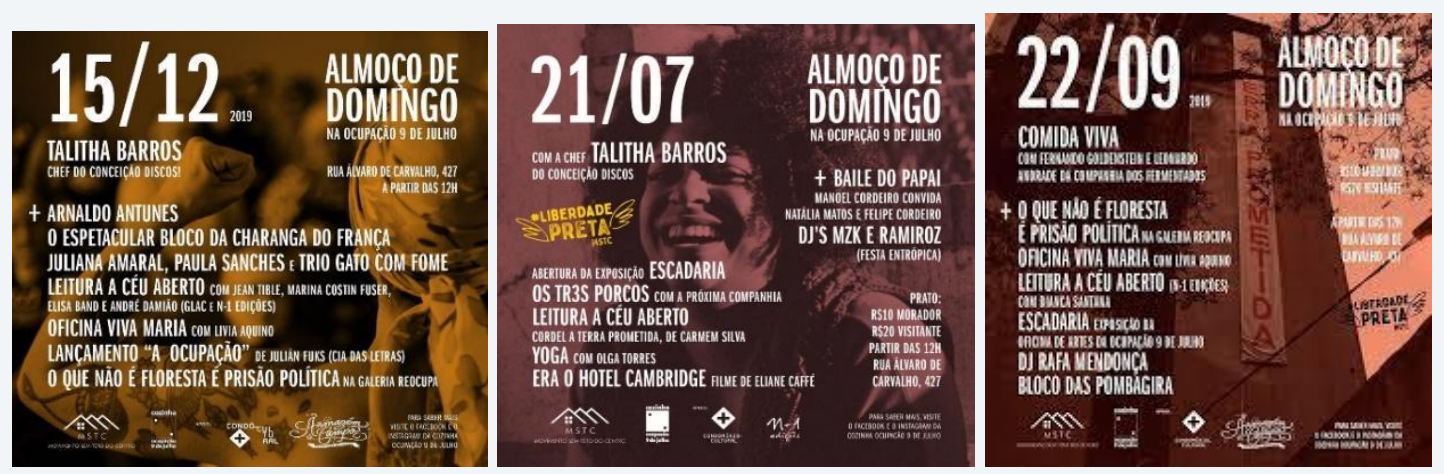

Rua Álvares de Carvalho, 427, região de São Paulo onde são abrigados muitos restaurantes e ofertas de serviços, próxima às ruas Augusta, Martins Fontes, Consolação. O portão de ferro, nem tão grande, nestes domingos fica aberto e deixa entrar a quem queira, mas que se identifique logo na porta: nome, registro geral, endereço eletrônico são identificações que servem como lastro a fincar cada um naquele lugar, ainda que a pessoa permaneça por poucas horas. A percepção de certa calmaria reunia pessoas que se cumprimentavam como se fossem antigos e bons vizinhos. Na Ocupação 9 de Julho vivem 122 famílias, desde 1997, num edifício do $\mathrm{INSS}^{6}$, sem cumprimento de sua função social há mais de três décadas. São onze andares usados como moradia e duas cozinhas coletivas com refeitórios onde são servidos os almoços.

\footnotetext{
${ }^{6}$ Instituto Nacional de Seguridade Social, Brasil.
} 
Num momento em que nos parece que as referências usadas para compreender o mundo estão ruindo, ou perdendo o sentido, nos esforçamos para refletir sobre dois gestos políticos que podem inspirar outros, a partir da compreensão de um modelo cooperativo de reprodução e partilhado com o cuidado e a consideração do bem viver. São eles: cozinhar e agregar mensalmente centenas, e até milhares de pessoas, dentro de uma Ocupação na produção de festas em que as crianças estavam presentes e delas participando entusiasticamente. Neste momento, discutir sobre almoços - na chamada Cozinha ${ }^{7}$ da Ocupação 9 de Julho - e uma festa para crianças - na Ocupação Mauá - faz-se também necessário. É uma, entre tantas formas de ouvir e registrar vozes há tempos silenciadas. Inspiradas na obra do artista plástico Kader Attia podemos afirmar que há reparos, não como restauração ou reforma, mas como mudança estrutural dos sentidos tomados até o momento por boa parte da humanidade e seus princípios, sobretudo, econômicos.

Nestes tempos pandêmicos os almoços e festas que envolvem crianças, obrigatória e responsavelmente, não têm acontecido. Recuperamos aqueles dos quais participamos no ano de 2019, afirmando que podem ser compreendidos como gestos que permitem refletir sobre formas de relações sociais que apontem para outros mundos possíveis na cidade - a São Paulo que aprendemos a ouvir que "não pode parar". Na vanguarda, promoviam formas de encontro entre pessoas e mais, colocavam em questão os espaços convencionalmente conhecidos para a arte, para almoços e confraternizações, geralmente exclusivos a grupos de pessoas conhecidas e de modo privado e os mostram eivados pela compreensão da capacidade abrangente das relações sociais e entre todas/os/es. Enquanto escrevemos pensamos que esses gestos estético-políticoafetivos provocavam a abertura de brechas para a emergência de estar junto presencialmente, da qual carecemos. Como sugere Bruno Latour (2020), devido ao isolamento físico imposto pela pandemia, estamos vendo que é possível desacelerar o capitalismo que, em sua versão ultra neoliberal, estampa e risca na carne a desigualdade social em sua forma absoluta, o que exige que pensemos urgentemente noutros modos de organização social. Afirmou que este é o momento de agir, talvez nas brechas, em que diante de uma retomada do mesmo modelo econômico e social, poderíamos dizer “de jeito nenhum”! (LATOUR, 2020, p. 04). Contudo, regulamos nossos otimismo e pessimismo, que, no contexto atual, se move como pêndulo. Embora seja visível a imensa solidariedade social que a pandemia impulsiona, sobretudo, nas favelas e organizações periféricas, sabemos que isso, por si, não muda o mundo. Caminhamos

\footnotetext{
${ }^{7}$ A palavra cozinha será escrita com inicial maiúscula C quando nos referirmos à Cozinha da Ocupação 9 de Julho isso deve-se à opção por não repetir muitas vezes a mesma referência.
} 
seguras/os nalgumas práticas que indiciam possibilidades de reflexão para projetar mudanças enquanto estamos em suspensão - num futuro exigente de alternativas políticas às orientações de uma ultra direita que se exibe afoita.

Iniciamos com algumas questões: Que tramas enlaçam a elaboração de cardápios para almoços dominicais? O que está implicado ao ato de servir e ser servido em reuniões regadas por boa comida e muitas pessoas? E quando essas práticas acontecem numa ocupação resultante de luta pelo direito à moradia num dos maiores centros urbanos do país, o que implica? O que significa o almoço seguido de outras ações acontecendo num mesmo espaço físico, tais como, shows, palestras, exposições em que as crianças são contempladas como sujeitos fundamentais à estas ações? Essas questões nos intrigaram ao longo de meses a cada ida à Cozinha da Ocupação 9 de Julho, local de onde partimos, não apenas para desfrutar de seus almoços saborosíssimos - mas refletir sobre eles.

O objeto de nossa atenção são as dimensões políticas e simbólicas presentes na proposta de almoços e que se ampliam para outras ações. $O$ almoço referido neste ensaio, é compreendido como festa em múltipla expressão, torna-se festa/imagem/texto/ato político que rompe com as tentativas de ocultar determinados locais da cidade com suas necessidades e desigualdades. Partimos do pressuposto de que a Cozinha da Ocupação 9 de Julho, e seus almoços mensais, compõe práticas que dignificam o ser humano e sua vida. Esses momentos de encontro são vistos como alimentos de processos de luta e, segundo nossas observações somadas à entrevista feita, implicam-se diretamente à vida de mulheres e meninas que transformam opressão histórica em expressão de libertação. É, inegavelmente, a proposta de outros modos de existência, ou uma nova percepção deste contexto em que luta sempre foi verbo.

\section{Cozinhas, crianças: tudo junto, antes e durante a Ocupação}

O que está implicado à uma cozinha? Pensar e tratar sociologicamente sobre as cozinhas e o esquadrinhamento das relações e cidades em espaços femininos, masculinos e mistos exige fôlego e escapa do escopo deste ensaio. Contudo, problematizá-la é importante, pois denotam representações resultantes de constructos sociais sobre essa parte interna ou externa da casa que indica e constrói representações e desígnios, sobretudo, das mulheres. A Cozinha, segundo nossa compreensão, é um ponto fulcral que arregimenta lutas e se espraia em outras formas de agir em comunidade, a partir e com as mulheres indiciando outros feminismos que comportam a vida das crianças, numa experiência social ativista. 
O estudo das cozinhas ao longo da história permite-nos compreendê-las, no século XIX e início do XX, como espaço fora da casa de forma mais comunitária, sem a conhecida cozinha separada do restante dos cômodos contendo apenas locais para cozer os alimentos e também como expressão da superposição das funções habitacionais nas moradias populares (LEMOS, 1978). Casas burguesas compõem uma espacialização sexuada que revela, constrói e mantém as relações de intimidade e constitui e define as esferas pública e privada, forma que prevalece como única entre muitos. As relações "no século XIX apresentam uma dicotomia entre os aposentos de recepção que dão para a rua e a cozinha que dá para o pátio, no final de um longo corredor que marcará a decoração e seu avesso" (PERROT, 1992, p.221) produzindo expectativas e práticas entre homens e mulheres no interior da casa. Sobre essas compreensões que expõem e mantém certa naturalização de alguns espaços da casa, sobretudo de modo generificado, bell hooks (2019) pondera sobre as relações que envolvem a cozinha e as mulheres, a casa e as mulheres ao desnaturalizar a branquitude com que sempre as observamos. Refletir sobre esses espaços implica relacioná-los a gênero, classe social e raça em diferentes contextos sociais e históricos que as atravessam provocando-nos a observar períodos em que o lar é objeto de subserviência ou de resistência das mulheres, especialmente as negras na primeira metade do século XX que lutaram - diríamos, ainda lutam - por transformar o lar como espaço de resistência e de luta pela libertação (op. cit, 107). Não podemos desconsiderar que esse espaço é também lugar de sofrimento para mulheres cujas energias são deixadas na casa branca, onde atuam como empregadas domésticas e depois em suas próprias casas, é também espaço de outras tantas formas de opressão às quais as mulheres são submetidas, a casa, lugar de aconchego para muitos, é o espaço onde estão concentrados os trabalhos mal vistos e não pagos. hooks (2019) nos leva a pensar sobre a cozinha como lugar em que se promove uma escrita da história das mulheres, e, por elas - ainda que de uma triste e opressiva história - que se evidencia nas relações com outras mulheres. Tomando como base as transformações do trabalho doméstico (FEDERICI, 2019), as lutas das mulheres negras e as políticas culturais (HOOKS, 2019), a cozinha da Ocupação 9 de Julho não é apenas objeto de estudo, mas porta-se como sujeito da história de lutas sociais ensejadas pelas mulheres neste momento, em que podemos iniciar a compreensão do trabalho afetivo envolvido na criação da cozinha, mas mais que isso, em seus desdobramentos produzindo certo bem estar comum em que é possível observar a diminuição da desigual divisão do trabalho entre homens e mulheres, sem que elas tenham a centralidade de trabalhos emocionais reproduzindo atividades historicamente acumuladas por elas, (FEDERICI, op. cit). Soma-se ao bem estar comum o caminho que alude ao "bem viver" como transformação civilizatória (ACOSTA, 2016). Esta 
última concepção embasa parte de nossas reflexões mais amplas e relacionadas à construção de pensamentos e propostas latino-americanas que entrecruzam ecologia, artes, economia não apenas como a sociedade de bem-estar ocidental. Embora importante, essa compreensão implica práticas que se identifiquem com a construção de visões sobre os marginalizados pela história que remetam ao abarcamento de oportunidades para construir coletivamente uma nova forma de organizar a própria vida que surja de raízes comunitárias e não capitalistas (ACOSTA, 2016, p. 89).

Entendemos que a Cozinha da Ocupação 9 de Julho está implicada a processos de mudança das práticas sociais femininas e feministas de modo bastante original, por envolver projetos das participantes ao longo de um denso processo de elaboração e apresentação do almoço, propriamente dito. A prática de Cozinha da Ocupação 9 de Julho, segundo entrevista com Fernanda ${ }^{8}$, uma das moradoras e contato entre pessoas de dentro e de fora da Ocupação, tem como resultado a construção de certa independência das mulheres. Há um processo que culmina no almoço. Chefs de cozinha envolvidas e envolvidos com seus restaurantes, dão aulas em cursos para as moradoras. Fernanda afirma que isso tem revertido em fonte de renda obtida com a venda de produtos que aprenderam a elaborar, seja dentro da ocupação nos dias de almoços, ou fora dela. Interessa refletir sobre a importância dessa conquista que vem somada à luta pela posse e manutenção da casa, em que majoritariamente prepondera a presença feminina com as crianças. Não acreditamos que isso signifique a reprodução do trabalho feminino, numa costumeira forma de compreender a cozinha como local emblemático da casa, expressão da submissão. Nosso esforço teórico é por compreendê-la como espaço de resistência que leva a uma renovação de si mesma. Assumir a liderança deste processo implica a recusa ao apagamento de experiências coletivas, a desconsideração de conhecimentos específicos e da luta acumulada pelas mulheres como forma de resistência à própria reprodução existente (FEDERICI, 2019). É oportunidade de reconexão com suas histórias nas relações estabelecidas entre elas. Ainda carecemos de maior aprofundamento nesta temática, mas reforçamos nossa afirmação de que há o prenúncio de outra composição concernente à mulher. O papel destas Ocupações para esta conquista é fundamental, pois tratam de vozes de mulheres que coletivamente constroem e afirmam um ponto de vista e experiências ainda pouco compreendidas.

Esta prática remeteu-nos aos movimentos sociais relacionados aos Clubes de Mães dos anos 1970-1980, nas periferias paulistanas em que a tessitura do diálogo contemplava a luta e

\footnotetext{
${ }^{8}$ Entrevista realizada no dia 08 de janeiro de 2020 nas dependências da Ocupação 9 de Julho.
} 
a burla de um cotidiano opressor. Concomitantemente nesses Clubes mesclava-se reflexões sobre as condições de vida e lutas diárias e se produzia escapes do cotidiano (SADER, 1989). Entendemos que compuseram processos fortalecedores dos modos como são dadas algumas das lutas atuais, ainda que vagarosamente, remetendo-nos ao entendimento da importância da junção de atividades como produção de sentido para a possibilidade de outra vida, sem opressão. Deixar certa concepção de casa particular e conjugá-la no plural das relações constitui-se como elemento fundamental, não apenas para refletirmos sobre a economia, mas para uma redefinição da produção coletiva entre pessoas sem a separação entre o pessoal e o político, o ativismo político e a reprodução da vida cotidiana (FEDERICI, op.cit, p. 352). O projeto da Cozinha enseja boas questões para pensar sobre seu potencial transformador na vida das pessoas que, de algum modo, se aproximam dela, sobretudo, daquelas que participam de todo seu processo até o almoço ser servido, mudanças nas quais seguramente as crianças estão envolvidas, direta ou indiretamente, há uma dimensão doadora que orienta a prática. Acreditamos que há uma força extrema nas formas cooperativas de organização, comportandose, talvez, como alavancas para outras formações sociais, e mais, como maneira de educação para novas práticas.

Mas, há algo importante a considerar neste momento em que escrevemos e analisamos a Cozinha e o que a envolve: não podemos dissociá-la da coexistência com o neoliberalismo e a ultra direita e suas práticas políticas e econômicas que esgarçam a exploração das/os trabalhadoras/es e do trabalho informal e consequente aprisionamento pelos endividamentos aos quais têm que se submeter. Ela reverbera tais condições e busca alterá-las. Deriva de questões que ecoam nas análises de Verônica Gago (2018) e sua análise sobre as subjetividades produzidas pelo neoliberalismo, o neoliberalismo de baixo, como definirá, enraizado nos territórios e nas vidas dos populares (p,22). Compreendemos, contudo, que essas práticas não configuram um processo revolucionário, como afirmará bell hooks (2019b). Percebe-se, no entanto, a presença de uma visão alternativa de mundo em que poderá residir o embrião da transformação radical de uma realidade opressora e estruturalmente desigual. A Cozinha e todo processo que repercute no almoço, são partes de um projeto que promove autonomia de algumas participantes ao evidenciar e questionar a opressão cotidiana e provocar a capacidade de criação de alimentos e sua venda impulsionando a construção de redes comunitárias. Escrever e refletir sobre a Cozinha é também estar atenta à dinâmica que resiste à exploração e à espoliação, num fazer em que prepondera o modelo cooperativo, num aprendizado de partilha dos cuidados e do viver, problematizando, ainda não eliminando as fronteiras entre o individual e o coletivo. Federici (op.cit) nos dá a tônica para o entendimento desta Cozinha como centro de uma vida 
coletiva. Talvez, encontre-se ali uma forma de reinventar a política, na expressão de conquistas de centralidade dos processos participativos e da produção de sua história. Essas práticas existentes nas Ocupações mostram-nos um princípio político democrático alternativo. Há um aprendizado de transformação da vida cotidiana. Embora careçamos de maior aprofundamento, compreendemos como aproximações ao "comum" aqui definido com Dardot e Laval (2019) como uma forma de contestar o capitalismo e um princípio político que define novo regime de lutas em escala mundial, não é a gestão coletiva de um bem comum determinado por uma comunidade, mas é um agir em comunidade e pelo comum e não para um único bem comum, há o predomínio de relações qualitativas entre as pessoas voltadas a diferentes causas eleitas como fundamentais à vida de todas/os/es.

Mas, o que essa Cozinha tem a ver com as crianças e com a cidade? Consideramos que os almoços envolvem uma proposta muito mais ampla do que meramente servir determinados pratos. Como já mencionado, eles estão imbricados de práticas que podem se comportar como germe de "outros mundos possíveis" em que a infância não está e não será descartada. Se as cozinhas têm o comum e certa libertação feminina, na compreensão de outros feminismos, as crianças estão com as mulheres. A Cozinha da 9 de Julho em alguma medida nos convoca a examinar a nós mesmas, aos usos destinados e conquistados dos espaços e aos movimentos sociais como embriões de transformação individual e social. Talvez, esteja nela a terra prometida dos movimentos sociais, em que tenhamos políticas públicas de igualdades igualitárias, como descreveu Carmem da Silva (2019, p, 12). As mulheres estão à frente da tropa, como diria a canção de Edgar Scandurra, e junto delas as crianças, mas não só, já que não se trata de mera reprodução de práticas naturalizadas, tidas como femininas. Como relata Carmem da Silva (op.cit) a luta é cotidiana, não dá para dizer "eu luto”, "eu vou lutar”, "eu vou fazer", "eu vou acontecer”, pra mim, é meu dia-a-dia (p, 25) e, consideramos que as crianças estão nesse mesmo caminho. Elas não se aprontam para uma luta específica, a moradia e a luta por moradia amarram essas vidas. 


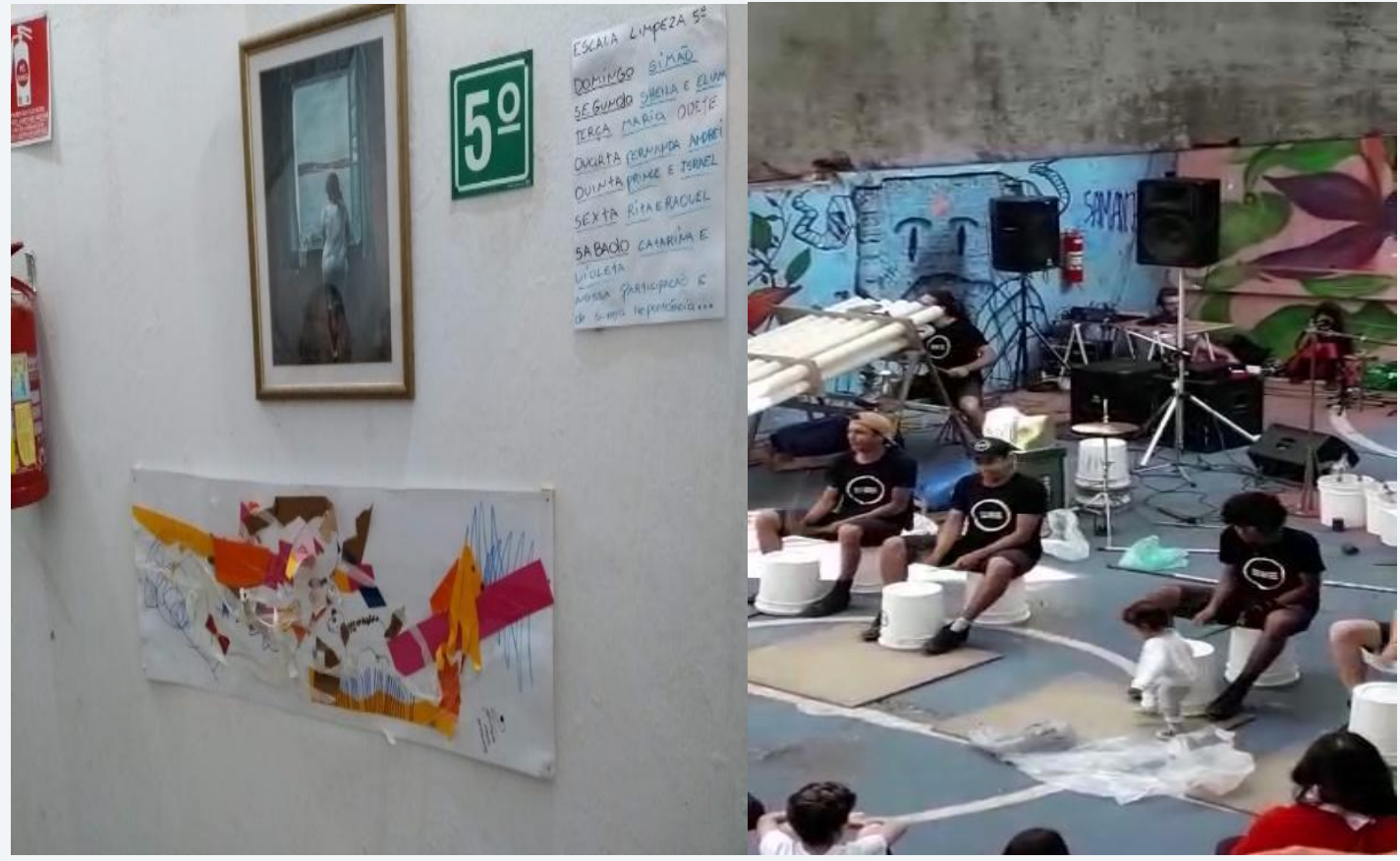

Marcia Gobbi; Ocupação 9 de Julho. Fonte: Arquivo pessoal.

A casa é um constructo social, entidade ou símbolo (RISÉRIO, 2019), podemos afirmar que casa é o que se chama e se sente como casa, assim, a Ocupação é uma casa, com outras tantas, que nalguns dias recebe milhares de pessoas e centenas de crianças que brincam juntas em seu terreno, nos pátios, nas hortas. Nela vivem muitas meninas e muitos meninos cujo cotidiano numa primeira olhadela é similar ao de tantas outras crianças. Ao firmarmos nossos olhares para o almoço da Ocupação percebemos que junto a eles há um extenso cardápio de brincadeiras, apresentações musicais, teatro voltados para as crianças, e, ao que percebemos ainda não construído por elas. Consideramos haver uma comunidade de resistência compartilhada e construída por mulheres na Ocupação e inferimos que isso se dá junto às crianças que se somam ao processo de transformação do cotidiano e à tentativa de criar igualitárias formas de viver. Entende-se a existência de uma investigação coletiva sobre o que apresentar para a criançada, sem deixar de discutir em outros horários sobre questões fundantes para as mulheres relacionando violência, políticas econômicas e sociais. Ao observar algumas imagens e relações presencialmente, vê-se as crianças misturadas com outras crianças e adultas, adultos, adultes durante as atividades.

As marcas das crianças constam do cotidiano da ocupação. Ao subir pelas escadas dentro da Ocupação nos deparamos com uma cena inusitada a cada andar alcançado: há uma exposição permanente de desenhos infantis nas paredes fruto das oficinas das quais as crianças - que querem - participam semanalmente e que é ministrada por uma artista plástica 
pernambucana. Há na sutileza do gesto infantil, exposto em traços sobre papéis entre molduras de madeiras, um ato que poderá envolver os passantes, moradores/as ou não, para a percepção ou aproximação do que as crianças estão elaborando entre elas. Destaco tratar-se de algo de extrema importância, pois a presença das obras elaboradas pelas crianças produz outros sentidos à moradia e as tornam, no mínimo, alvo de seus olhares, aprende-se sobre crianças a partir daquilo que elas criam, ressalta-se que as paredes que circundam as escadas tornam-se espaços de produção de pensamento sobre a infância. Suas criações compõem o cotidiano. Dado o limite de um ensaio, não podemos incluir aqui tantas imagens, contudo, ressaltamos que o convite feito para que trilhemos um caminho imagético de criações infantis torna, ou pretende tornar, legível e visível a presença de meninas e meninos e suas histórias cotidianas. Didi-Huberman (2019) afirmará que as obras-primas só existem para um mundo e que é preciso, para apreendêlas enquanto tais, referi-las ao mundo que as descobriu (p.05). Mas, inspiradas em suas considerações podemos refletir sobre obras de crianças, que passam a existir para um mundo, não o das artes já consagradas e seus conhecidos mercados, mas um mundo em que vivem e onde podem tornar suas criações referências para circuitos de relações, nas ocupações e com os de fora delas. Temos a possibilidade de ter conosco as histórias de crianças que ocupam os espaços transformando-o em lugar, que é também delas e por elas. Inusitado, justamente pela ausência das crianças e suas produções na composição de espaços públicos na cidade e nos edifícios habitados por elas, onde a ausência se faz presença frequente que acobertada a infância e seus artefatos culturais.

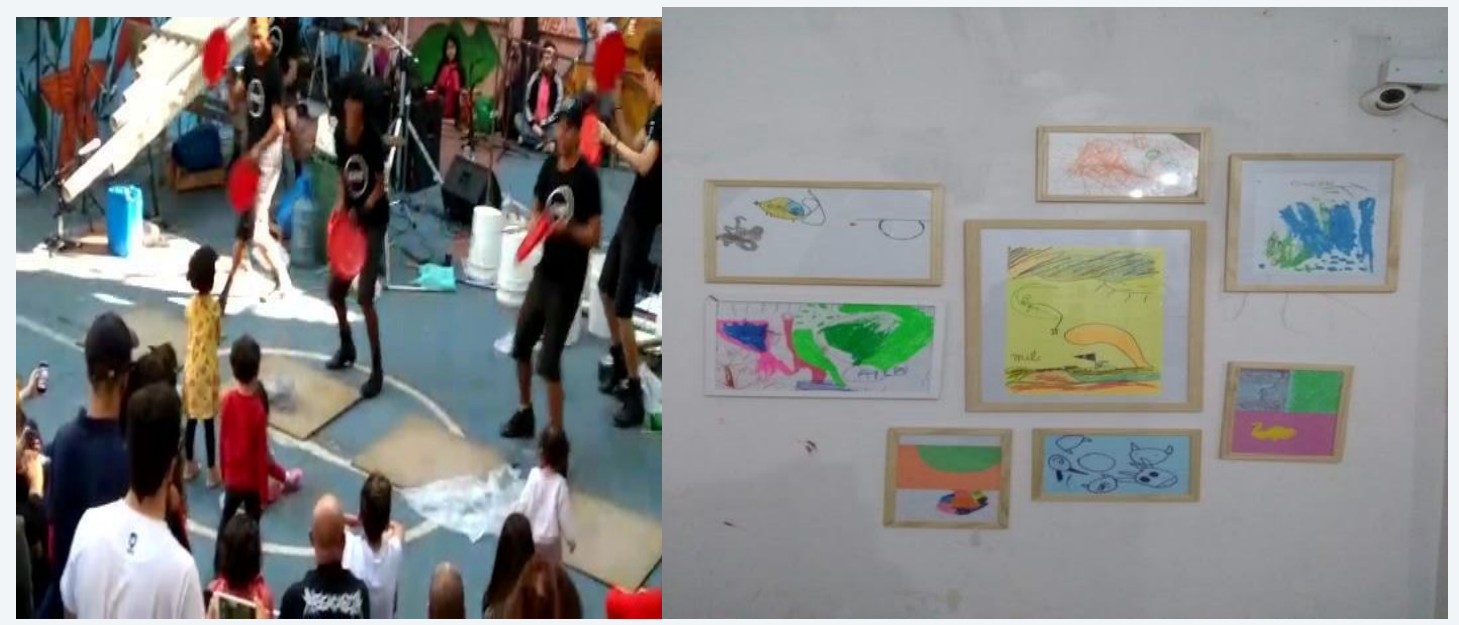

Marcia Gobbi; Ocupação 9 de Julho. Fonte: Arquivo pessoal.

Observamos com a presença das crianças na programação que acompanha os almoços um interstício, brecha que aponta para possível apropriação da cidade e da vida vivida pelas crianças, ainda que seja uma pequena contribuição para a descatracalização de suas vidas 
promovendo o encontro com os outros e com suas produções no prenúncio de certo engajamento que contém as crianças.

\section{Cores e pipocas na Mauá: as crianças e as centralidades ocupadas}

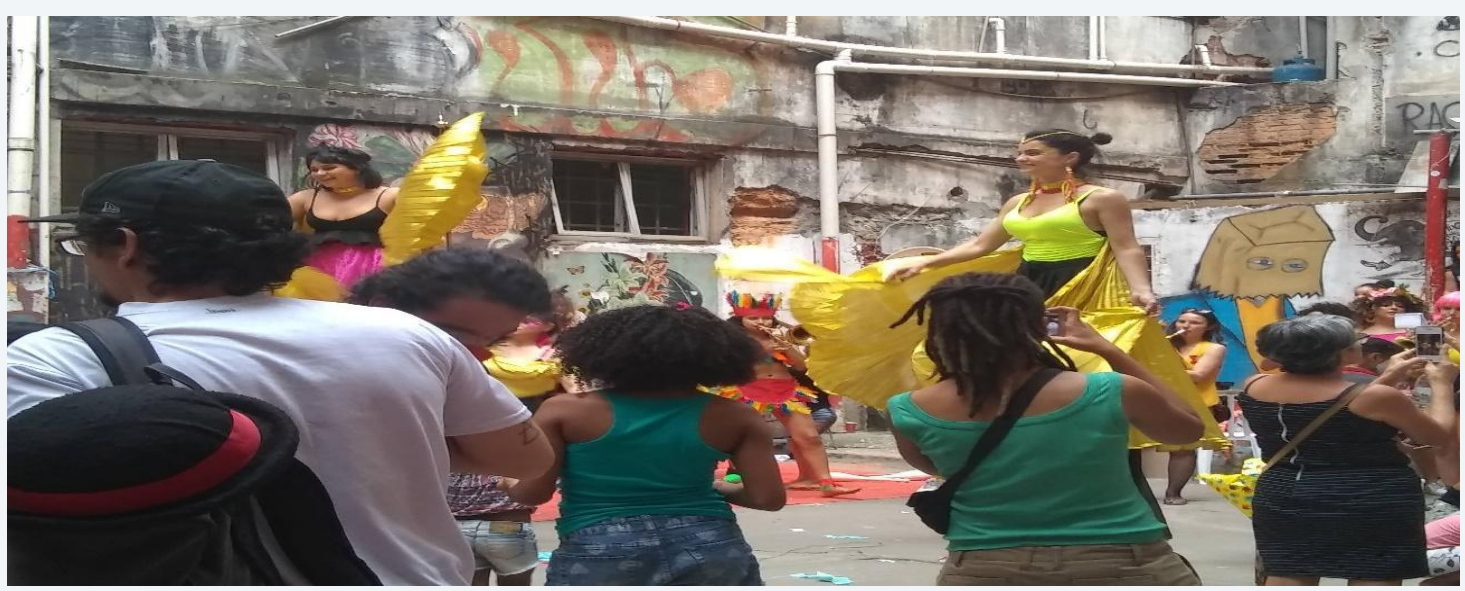

Marcia Gobbi; Ocupação Mauá. Fonte: Arquivo pessoal.

Rua Mauá, 340, região conhecida como o Centro Histórico da Cidade de São Paulo, em frente à Estação da Luz. Sábado, 12 de outubro de 2019, Dia das Crianças. O pequeno portão, comumente fechado, encontrava-se aberto nesse dia. Música e as crianças que transitavam logo no corredor de acesso ao pátio indicavam que se organizava uma festa, uma festa de dia das crianças na Ocupação Mauá. Ali vivem atualmente mais de 300 famílias, em um prédio antes desocupado, onde funcionou o Hotel Santos Dumont, de 1953 à meados dos anos 80.

Se ao pensar os almoços da Ocupação 9 de julho nossas reflexões foram tecidas em torno da cozinha, da elaboração dos cardápios e das relações implicadas com as mulheres e crianças, aqui, trazemos para o centro da discussão a "festa". Na luta por moradia a festa pode assumir diferentes significados, caracterizando, por exemplo, a ação de ocupação de prédios/terrenos em desuso, que não cumprem sua função social ${ }^{9}$. Nesse sentido, muitos são os fios possíveis de serem usados para tecer compreensões, mas por ora, no limite deste ensaio, limitamo-nos a compartilhar algumas breves reflexões constituídas a partir da nossa participação na "festa do dia das crianças", portanto não qualquer festa, mas aquela produzida para as crianças e com elas no dia-a-dia que a antecedeu. Embora houvesse nítido desejo de esconder da criançada que haveria uma festa para elas, para que fosse uma surpresa, o fato é que, pelos mais diferentes motivos, elas participavam de alguns momentos de organização. É festa para crianças, mas quando ela acontece em uma ocupação na região central da cidade de

\footnotetext{
${ }^{9}$ Indicamos o documentário “Dia de Festa” (2006), de Toni Venturi.
} 
São Paulo, o que significa? Afinal, o que há por trás de uma festa? Esta foi nossa questão levantada, cujas respostas derivam de pesquisas realizadas em outros dias e situações em que estivemos presentes.

Durante a apresentação de um coletivo artístico de música, bebês e crianças pequenas observam, ora de longe, ora arriscando chegar mais perto, parecendo curiosos em especial pelos instrumentos que acompanhavam o grupo. Algumas crianças pintavam em papéis e tintas disponibilizadas no chão do pátio da Ocupação; outras ainda corriam e brincavam com seus amigos. Uma menina maior, acompanhada das irmãs menores, segura uma delas, bebê, no colo. A bebê que observava a apresentação com olhar atento, chupando um pirulito, começa a mostrar-se inquieta, choramingando, esfregando os olhos, parecendo estar com sono. A irmã logo a aninha nos braços, aconchegando-a, balançando-a de um lado a outro para que adormecesse. Aproximo-me e pergunto se a bebê conseguiria dormir, prevendo um incômodo com o som alto. A menina diz que sim e completa: "ela está acostumada". Em poucos minutos, a bebê adormece (Caderno de campo, outubro de 2019).

Partimos da descrição de uma cena para pensar a festa como prática social de compartilhamento e sociabilidade, como espaço de experiência estética, mas também e, inclusive, como ato político. Como já dissemos, o objeto de nossa atenção são as dimensões políticas e simbólicas presentes, tanto nas propostas dos almoços, quanto na festa das crianças, que entre tantas outras atividades, confere centralidade às meninas e meninos de todas as idades, momento em que a ocupação, em que as crianças são constantes com suas vozes e práticas, fica ainda mais impregnada de infância. Mais do que problematizar a existência dessa data comemorativa em nosso calendário festivo, certamente de cunho comercial, optamos em considerá-la como propulsora de importantes chaves para se pensar as crianças e a infância nas ocupações. Ao problematizar o que há por trás de experiências como esta - da festa do dia das crianças - consideramos as relações estabelecidas entre elas, e delas com as pessoas moradoras e não moradoras da ocupação. Há algumas questões, pois ao longo da preocupação com a organização observa-se a centralidade que vem sendo ocupada pelas crianças a partir do que se compreende por infância e por crianças. Há uma variação que fica entre compreendê-la com seus direitos à festa, assim como todas as demais, e a percepção delas como copartícipes no processo, ou seja, a festa é também pensada por elas, embora não tanto quanto poderiam. A organização se dá, majoritariamente, pelos chamados voluntários, grupos que participam com inúmeras atividades junto à Ocupação e fazem parte, em alguma medida, de seu cotidiano. Nete, como é conhecida Ivanete Araújo, coordenadora do movimento Luta por Justiça e muitíssimo importante na Mauá, em várias conversas ressalta a importância destes grupos como apoiadores que reconhecem a luta dos moradores e moradoras e estão ao lado dela. São "outro braço da luta, tão importante quanto a parte da moradia" (SANTOS, 2018, p. 161). Nos últimos anos 
e, especialmente, e mais recentemente acentua-se a importância da presença destes grupos como alimento, não para a luta por moradia, propriamente dita, mas para sua manutenção e reconhecimento de sua importância para a cidade.

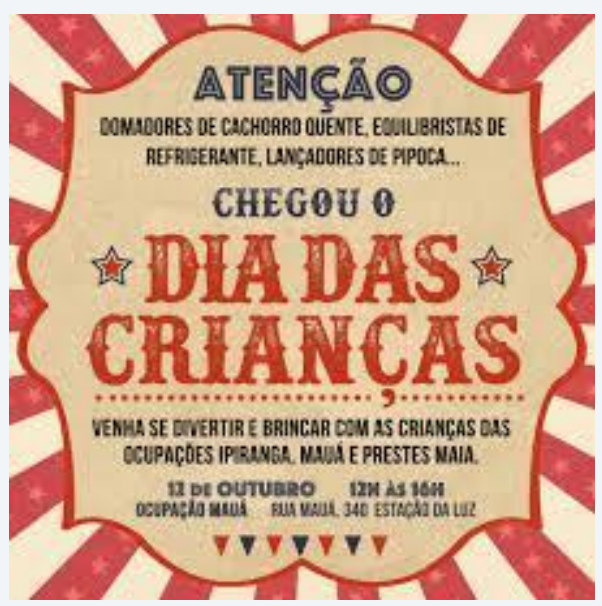

Recebemos via aplicativo whatsapp, o reforço ao convite para participar da festa. Em formato de circo, com promessas de diversão e um cardápio recheado de guloseimas. Ora, se iniciamos nossa reflexão sobre a Cozinha na Ocupação 9 de julho questionando quais tramas entrelaçam a escolha dos cardápios dos almoços dominicais, aqui ousamos trazer tais questionamentos: que tramas entrelaçam a escolha do cardápio, da temática, da programação desta festa? Se há, no alimento produzido coletivamente na cozinha a possibilidade de rupturas e mudanças sociais, o que dizer quando o alimento não é produzido com, mas compartilhado com as crianças? Ao mesmo tempo em que conferem centralidade às crianças, que avaliamos ser uma conquista das próprias crianças provocativas aos adultos e às adultas em sua constante presença e solicitações diversas, o que faz crer certas singularidades existentes nelas e entre elas, há alguns comportamentos que as aproximam de certas formas simplificadas de compreensão das crianças com o que há de mais comum e presente entre os adultos e as adultas. Tínhamos a compreensão de modos de lidar com essa situação festiva que partia das crianças e outra que era produzida pelas adultas moradoras da Ocupação e ainda outra vinda das apoiadoras e apoiadores. A mescla de grupos permitia ver certas nuances de diferenças entre os diferentes agentes que mostravam suas concepções de crianças e do que é a infância numa Ocupação. O comum é a agenda construída exclusivamente pela presença das meninas e meninos, desde bebês.

Universos festivos e festas são produções sociais e culturais com potencial socializador que constituem o cotidiano intensificando sua complexidade com rituais e relações que, porventura, podem fornecer certas mudanças à programação das vidas envolvidas e conferem 
especial marcação de passagem. Nesse sentido são também construções históricas e simbólicas, que contêm muitas facetas e podem evidenciar os lugares ocupados pelos sujeitos nas estruturas sociais. Sirota (2008) ao refletir sobre as festas de aniversários infantis, por exemplo, destaca a inversão da ordem geracional das festas familiares na França, no século XX: o ancião antes festejado e considerado o núcleo das comemorações familiares, são, aos poucos substituídos pelas crianças. Assim, a escolha da temática, do cardápio, da programação de festas infantis, que pressupõem traduzir interesses das crianças, evidenciam escolhas que são produzidas em tempos e espaços determinados, que conjugam elementos culturais que dão forma a um universo imaginário da infância. Quando tratamos de crianças nas ocupações, observamos que as festas evidenciam sua centralidade na ocupação, e portanto, na luta por moradia, e em decorrência disso, da infância como objeto de interesse e discussão, sobretudo, na coordenação da luta e deste movimento social particularmente.

Ao afirmar a existência de diferentes significados de infância nas escolhas em torno de uma festa, Sirota (op.cit) destaca a presença do bolo de aniversário, segundo ela a encarnação do rito em um objeto, que reflete a simbologia tecida em torno da festa de aniversário infantil. Consideramos importante a observação, porém, não podemos generalizá-la, já que há, seguramente, outros marcadores rituais dessa festa com e para as crianças. Interessa-nos destacar os possíveis e perceptíveis agenciamentos destas festas para as crianças e transformações produzidas. A presença da festa, segundo nossas observações, indica um processo, ainda que vagaroso, pelo qual passa a luta por moradia, nesse movimento e grupo específicos. Ao conversar com algumas das coordenadoras de forma livre sobre Ocupação e as crianças moradoras sentia-se certa afecção em relação a infância, uma preocupação, ainda que incipiente, com seus direitos implicados ao direito à moradia. Entendemos sua capacidade agenciadora ao percebermos que a festa promove o envolvimento do grupo de adultos e crianças o que repercute em diálogos posteriores sobre elas. Ou seja, ela impulsiona e traz em si o potencial de fazer reflexões, que, no limite, podem gerar mudanças concernentes à presença das crianças nos caminhos da luta por moradia e cidade.

Nesse sentido, se cachorro-quente, suco e pipoca, desenhos, pinturas e bolhas de sabão, que compõem o cenário da festa das crianças na Ocupação, nos dão pistas para pensar a representação e o lugar social que elas ocupam, há que considerar como ele é interpelado pela participação de coletivos urbanos artísticos que produzem com elas o espaço, alteram o ritmo da festa ao fazerem apresentações de músicas com mensagens sociais e palavras de ordem, por exemplo, que se misturam as corridas, aos gritos, as tintas, aos desenhos e as brincadeiras das crianças. Se há aqui a possibilidade da experiência, tal qual traduzido por Larrosa (2002), como 
aquilo que passa, sente e toca o sujeito, pode-se dizer que ela é estética, mas ela é também política. Uma experiência fundamentalmente urbana, da prática, do mundo vivido na luta por moradia, entrelaçada à arte. É uma festa de crianças na ocupação, que "estão acostumadas", conforme evidencia a menina descrita em nosso breve relato sobre a festa; brincam ao mesmo tempo em que repetem "quem não luta, tá morto", em alusão a recorrente fala da coordenadora do movimento, Ivanete.

Há aqui outra importante questão a ser destacada: ainda que, de antemão, fosse possível afirmar que essa era uma festa produzida por adultos, uma festa dos adultos para as crianças, há uma ação delas evocada em sua própria presença ao correr, transitar pela festa, ao solicitar o instrumento do músico em meio a sua apresentação, em choramingar e dormir, em desenhar, brincar e se relacionar de maneira própria, como estão e compõem o mundo, traduzindo, a sua maneira, sua presença e histórias no cotidiano da Ocupação. As crianças participam, interagem e transformam a festa.

"Eu adoro a Mauá, porque aqui tem muita festa", afirma uma das meninas que nos acompanha durante a atividade, o que nos leva a pensar que morar na Ocupação marca identidades sociais, construídas na relação com o tempo, espaço e grupos que se ali se misturam. No caso da festa, grupos “de dentro" (de moradores e moradoras), que se misturam com os "de fora"; de bebês, crianças e adultos que estabelecem novos gestos e relações sociais na arte do encontro com o outro, que ocorre, para essas crianças, no "quintal de casa". Casa que por sua vez encontra-se no centro da cidade de São Paulo: um espaço complexo, marcado pela diversidade, mas, como ressalta Tourinho (2006), longe de ser considerado democrático: é espaço do conflito, marcado por segregações. Desta forma, nesta cidade cada vez mais estabelecida como espetáculo do consumo, de ruas como espaços de passagem, do shopping como espaço de lazer (CARLOS, 2017), do espaço público atrofiado em sua condição de espaço de sociabilidade (VOLOCHKO, 2015), a festa na Ocupação pode também ser compreendida como uma instigante possibilidade de ocupação e apropriação, no sentido de um "uso que se realiza através do corpo e de todos os sentidos humanos e a ação humana se realiza produzindo um mundo real e concreto delimitando e imprimindo "rastros" da civilização" (CARLOS, 2017, p. 183). Trata-se, portanto, de compreender, tal qual na Cozinha da Ocupação 9 de julho, a festa como a brecha, como espaço do encontro em que se deixam rastros, da sociabilidade, da criação, da experiência estética e política, que a torna, de maneira muito peculiar, uma manifestação da luta pela cidade, que ocorre junto às crianças. 


\section{Mulheres e crianças nas ocupações e a escrita de outra história da cidade: considerações finais}

Este ensaio teve como objetivo apresentar recortes de observações que derivam de pesquisas em ocupações tendo as mulheres e crianças como centro de nossas investigações. Optamos por trazer registros de práticas urbanas em que as crianças são consideradas presentes promovendo outras formas de pensar a cidade, qual seja, em associação entre mulheres e crianças. A observação destes momentos dentro das Ocupações permitiu-nos formular um problema a partir da identificação de um princípio político que confere sentido ao movimento social em oposição a uma gramática social restritiva e excludente. Há uma relação com o outro que nos tocou a pensar sobre a existência, talvez embrionária, do comum, na concepção de Pierre Dardot e Christian Laval (2019), sendo a produção do alimento e demais desdobramentos disso uma maneira de construir comuns. Há várias outras, porém, todas implicadas à produção de regimes de luta e a preservação da vida contra as históricas agressões já sofridas e que, nos parece, intentar a devolução e/ou construção da força coletiva, por vezes, não mais percebida e então levada a assujeitar-se. São as mulheres, da cozinha, que com sua forma de dizer e fazer, nos mostram saídas comuns, com perspectiva igualitária, talvez expressão da quarta onda feminista, nas palavras de Heloisa Buarque de Hollanda (2018), um feminismo na e da cozinha, que se faz também, mas não só, com as crianças.

Discutir sobre infância e cidade tem exigido atenção para diferentes focos em que as crianças oriundas de distintos espaços estejam presentes. Escrever sobre cidade implica considerar do que ela é feita: as presenças que a constituem como ela é. As crianças negras, pobres, periféricas, moradoras de ocupações, indígenas, em situação de rua, entre tantas outras marcam e fazem a cidade a seu modo, portanto, se queremos considerar que discutir sobre a cidade se faz a partir das crianças e considerando seus pontos de vista, é imprescindível que todas elas sejam consideradas em suas vozes, desejos, necessidades o mesmo ocorrendo com as mulheres, que, entendidas aqui não somente como reprodutoras, mas inventoras de tantas outras formas de luta e de conquistas e, nas palavras de Silvia Federici, nas batalhas pelos comuns, presentes na constituição dos movimentos sociais aqui mencionados e que não se fazem sozinhos, as crianças implicam outros tempos à luta e formas de travá-la e compreendêla. Nosso recorte não permite trazer tantas vozes, muito poucas se apresentaram, nosso intuito foi apenas uma aproximação ao tema. A presença marcante das mulheres deveu-se ao fato de que elas constroem lugares diversos onde e como morar junto e pelas crianças. Como visto, na Cozinha da Ocupação 9 de Julho, as crianças estão presentes e misturadas a tantas outras de 
"fora", ao mesmo tempo, nesta mesma Ocupação, suas criações artísticas estão lá, marcando o cotidiano dos moradores e das moradoras. A centralidade vista e sentida está presente na Ocupação Mauá. Destacamos uma festa, contudo, certo costume da criançada revela ao mesmo tempo centralidade e outra forma de estar junto entre todos numa maneira de lidar com o outro que inspira certa comunhão, ao mesmo tempo em que exige mais investigações. O que está por trás de uma festa ou de um almoço é muito amplo e este ensaio apenas tocou de leve alguns de seus aspectos objetivando provocar outros pensamentos e diálogos sobre o assunto. $\mathrm{O}$ que sabemos é que há uma outra história de cidade e, reforçamos, do Brasil que está sendo contada por estas crianças e mulheres nas Ocupações. Há outras histórias que carecem ser escritas e que ainda pouco ou nada conhecemos e que trazem a presença de pessoas por muito tempo não vistas ou desconsideradas num histórico e longo apagamento de suas vidas. Se, como tantos têm dito nesses tempos de pandemia, podemos sair melhores deste momento, não sabemos ao certo, acreditamos que muito deve ser feito. Porém, para isso, há que considerar algumas práticas já existentes e interrompidas devido a Covid-19, entre elas, acreditamos que as experiências em que tocamos neste ensaio são extremamente fecundas para se pensar noutros modos de existência, elas nos inspiram, sobretudo, por tratar de conquistas de outros espaços e processos participativos, por mostrarem formas de reciprocidade como fundamento das relações, por tratarem de modo solidário e promoverem aprendizados de vínculos sociais no cotidiano citadino. Há que refletir e aprender.

No momento em que terminamos este ensaio a pandemia ainda mata milhares de pessoas diariamente no Brasil, em especial, negros e pobres em curva crescente. Há muito o que fazer. Mas as atividades descritas, embora inativas para um público mais amplo, como nos almoços e festas mencionadas, atualmente têm ecos internos o que configuram e remetem à urgência de análises sobre as sediciosas formas de viver que amalgamam mulheres e crianças num constante e inventivo modo de se constituir na cidade tratando e produzindo solidariamente soluções que restituem e mantém a vida. A Cozinha da 9 de Julho funciona a todo vapor e produz marmitas para moradores de outros bairros paulistanos e a Mauá se faz na divisão de doações de alimentos e produtos de limpeza entre as famílias de moradores e moradoras de outras ocupações. Há o que aprender com essas práticas e experiências na cidade que são orientadas por movimentos de luta por moradia e por pessoas, adultas e crianças que as fazem diariamente contando outras histórias possíveis. 


\section{REFERÊECIAS}

ACOSTA, Alberto. O Bem Viver: uma oportunidade para imaginar outros mundos. São Paulo, Editora Elefante, 2016.

CARLOS, Ana Fani Alessandri. Espaço-Tempo da Vida Cotidiana na Metrópole. São Paulo: Labur Edições, 2017.

CERTEAU, Michel de. A invenção do cotidiano. 1. Artes de fazer. Petrópolis: Vozes, 1994.

DARDOT, Pierre e Laval, Christian. Comum: Ensaio sobre a Revolução no Século XXI. São Paulo, Editora Boitempo, 2019.

DIDI-HUBERMAN, Georges. Sobre o fio. Florianópolis: Editora Cultura e Barbárie, 2019.

FEDERICI, Silvia. O ponto Zero da Revolução. São Paulo: Editora Elefante, 2019.

GAGO, Verônica. A razão neoliberal: economias barrocas e pragmática popular. São Paulo, Editora Elefante, 2018.

HOLLANDA, Heloisa Buarque. Explosão Feminista. São Paulo: Editora Companhia das Letras, 2018

HOOKS, bell. Anseios. São Paulo: Editora Elefante, 2019

LATOUR, Bruno. Imaginar gestos que barrem o retorno da produção pré-crise. São Paulo:Editora N-1, 2020.

LARROSA, Jorge. Notas sobre a experiência e o saber de experiência. Revista Brasileira de Educação. Campinas, nº 19, p. 20-28, jan./fev./mar./abr, 2002.

LEFEBVRE, Henri. La Producion del espacio. Espanha: Madrid. Editora Capitán Swing, 2013.

LEMOS, Carlos Alberto Cerqueira. Cozinhas, etc. São Paulo: Editora Perspectiva. 1978.

NETO, Sebastião Oliveira. Situação Prestes Maia. São Paulo: Invisíveis Produções, 2019.

PERROT, Michelle. Os excluídos da história: Operários, mulheres, prisioneiros - São Paulo, Paz e Terra, 1988. Coletânea de artigos organizados por M. Stella Brescianni.

RAMOS, Nuno. Brasil enfrenta duplo apocalipse com Bolsonaro e coronavírus, reflete Nuno Ramos. Folha de São Paulo, 3/05/2020.

RISÉRIO, Antonio. A casa no Brasil. São Paulo: Editora TopBooks, 2019.

SADER, Eder. O Clube de Mães da periferia sul de São Paulo, In: Quando novos personagens entraram em cena: experiências, falas e lutas dos trabalhadores da Grande São Paulo, 1970-80. Rio de Janeiro: Paz e Terra, 4ª edição 2001.

SANTOS, Renato Abramowicz. Cartografias políticas de uma ocupação - cotidiano, território e conflito. Dissertação (Mestrado) - Faculdade de Filosofia, Letras e Ciências Humanas. Universidade de São Paulo (USP). São Paulo, 2018. 
SANTOS, Solange Estanislau dos; ANJOS, Cleriston Izidro dos; FARIA, Ana Lúcia Goulart de. A criança das pesquisas, a criança nas pesquisas... A criança faz pesquisa?. Práxis Educacional, [S.1.], v. 13, n. 25, p. 158-175, abr. 2017. ISSN 2178-2679. Disponível em: <http://periodicos2.uesb.br/index.php/praxis/article/view/958>. Acesso em: 06 jun. 2020. doi: https://doi.org/10.22481/praxis.v13i25.958.

SILVA, Carmen da. A Terra Prometida. São Paulo, Editora N-1, 2019.

SIROTA, Régine. As delícias de um aniversário: uma representação da infância. Revista Eletrônica de Educação, v. 2, n. 2, nov. 2008.

TOURINHO, Andrea de Oliveira. Centro e centralidade: uma questão recente. In: CARLOS, Ana Fani; OLIVEIRA, Ariovaldo Umbelino (Org.). Geografias das Metrópoles. São Paulo: Contexto, 2006.

VOLOCHKO, Daniel. Nova produção das periferias urbanas e reprodução do cotidiano. In: CARLOS, Ana Fani (Org). Crise urbana. São Paulo: Contexto, 2015.

\section{SOBRE OS AUTORES:}

\section{Marcia Aparecida Gobbi}

Possui Doutorado em Educação pela Universidade Estadual de Campinas. Professora da Faculdade de Educação da Universidade de São Paulo, atuando nos cursos de Licenciatura em Ciências Sociais e de Pedagogia e junto ao Programa de Pós-Graduação em Educação. Atualmente dedica-se a investigar representações e criações da infância em luta por moradia em ocupações na cidade de São Paulo. Coordenadora do grupo de Estudos e Pesquisas "Crianças, práticas urbanas, gênero e imagens" (CNPq/FE/USP). E-mail: mgobbi@usp.br

iD http//orcid.org/0000-0001-9850-01901

\section{Cleriston Izidro dos Anjos}

Possui Doutorado em Educação pela Universidade Federal de Alagoas. Professor do Centro de Educação da Universidade Federal de Alagoas, Membro do Corpo Docente do Mestrado em Educação Pré-Escolar da Universidade Katyavala Bwila (Angola), Membro Colaborador Doutorado do Centro de Investigação em Estudos da Criança da Universidade do Minho (Portugal) no grupo "Contextos, quotidianos e bem estar da criança". Atua principalmente nos seguintes temas: Educação Infantil, Formação Docente, Linguagens Expressivas e Culturas das Infâncias. Coordenador do GEPPECI - Grupo de Estudos e Pesquisas em Pedagogias e Culturas Infantis (CNPq/CEDU/UFAL). E-mail: cianjos@yahoo.com.br

iD http://orcid.org/0000-0003-1040-4909

\section{Juliana Diamente Pito}

Possui Mestrado em Educação pela Pontifícia Universidade Católica de São Paulo e é estudante de doutorado pela Faculdade de Educação da Universidade de São Paulo. Atua como professora do Núcleo de Educação Infantil Paulistinha - UNIFESP. E-mail: jdiamente@hotmail.com

iD http://orcid.org/0000-0003-0850-4249

Recebido em: 11 de fevereiro de 2020 Aprovado em: 10 de maio de 2020 Publicado em: 01 de julho de 2020 